\title{
PHOTOSENSITIVITY AND HEAT RESISTANCE CONFERRED BY BIdU INCORPORATION UPON A THYMIDINE KINASE-DEFICIENT MOUSE CELL LINE WITH PERSISTENT MITOCHONDRIAL ENZYME ACTIVITY
}

G. ATTARDI, BENNETA KEELEY AND CATHERINA TU

Division of Biology, California Institute of Technology,

Pasadena, California 91125, U.S.A.

\section{SUMMARY}

The $\mathrm{LM}\left(\mathrm{TK}^{-}\right) \mathrm{Cl}$ ID cell line, a thymidine kinase-deficient derivative of mouse $\mathrm{L}$ fibroblasts with persistent mitochondrial enzyme activity, can incorporate thymidine and 5-bromodeoxyuridine (BrdU) into mitochondrial DNA (mit-DNA) at a substantial rate, in the absence of any significant incorporation of these precursors into nuclear DNA. Furthermore, these cells can be grown indefinitely in the dark in the presence of $30 \mu \mathrm{g} / \mathrm{ml} \mathrm{BrdU}$. In the present work, advantage was taken of these properties to investigate the possible photosensitizing effect of BrdU which would depend on its incorporation into the organelle DNA, in the absence of nuclear effects.

$\mathrm{LM}\left(\mathrm{TK}^{-}\right) \mathrm{Cl}$ ID cells, which had been grown in medium containing $30 \mu \mathrm{g} / \mathrm{ml} \mathrm{BrdU}$ or in BrdU-free medium, were irradiated for different lengths of time with 'visible' light, in the presence or absence of the halogenated precursor, respectively. 'Visible light' indicates the source of light used, although the components most active photochemically on BrdU-substituted DNA are in the near-visible range (300-340 nm) (Szybalski \& Opara-Kubinska, I 965).

A two- to several-fold decrease in growth rate of mass cultures and an exponential decline in cloning forming capacity with a half-life of $2-3 \mathrm{~h}$, after a lag of a few hours, were observed during irradiation both of cells grown in the presence of BrdU and of cells grown in its absence, the effects being somewhat more pronounced in BrdU-maintained cells. In cells maintained in BrdU-free medium, this loss of cell viability could be almost completely reversed if the irradiated cultures were trypsinized and replated either for mass growth or for cloning experiments. On the contrary, the reversal of the irradiation effects by trypsinization and replating was only partial in the case of BrdU-grown cells: these exhibited, in fact, after increasing periods or irradiation, without any significant lag, an exponential loss of cloning efficiency with a half-life of about $8 \mathrm{~h}$ down at least to $0.1 \%$ survival. Control experiments showed that the photosensitivity of $\mathrm{Cl}$ I D cells required their previous exposure to the halogenated precursor, and did not depend on the presence of BrdU in the medium during irradiation.

An estimate of the possible residual extramitochondrial thymidine kinase activity in $\mathrm{Cl} I \mathrm{D}$ cells, as compared to that of $A_{9}$ cells, another $\mathrm{L}$ cell derivative with normal enzyme activity, was obtained from the relative incorporation of $\left[\mathrm{Me}^{-3} \mathrm{H}\right]$ thymidine into total cell DNA in the 2 cell lines. From this estimate and from the photosensitivity of A9 cells grown for 2 or 3 generations in the presence of $30 \mu \mathrm{g} / \mathrm{ml} \mathrm{BrdU}$, it can be calculated that the photosensitivity of $\mathrm{Cl}$ ID cells is about an order of magnitude higher than expected from any possible residual incorporation of BrdU into nuclear DNA, if this were random. The present results are, on the contrary, compatible with the idea that mit-DNA is the killing target of 'visible' light irradiation.

An increased thermoresistance, as revealed by measurements of growth capacity of mass cultures and by cloning efficiency determinations at $40^{\circ} \mathrm{C}$, was observed in BrdU-grown $\mathrm{Cl}$ ID cells in comparison with cells maintained in the absence of the halogenated precursor. 


\section{INTRODUCTION}

Work from this and another laboratory (Attardi \& Attardi, 1972; Clayton \& Teplitz, I972) has shown that, in a thymidine kinase-deficient derivative of mouse $\mathrm{L}$ cells $\left[\mathrm{LM}\left(\mathrm{TK}^{-}\right) \mathrm{Cl} \mathrm{ID}\right]$, the loss of the extramitochondrial thymidine kinase activity is not accompanied by loss of the mitochondria-associated enzyme activity, pointing to a different genetic or epigenetic control of the extramitochondrial and mitochondrial enzymes. This property of $\mathrm{LM}\left(\mathrm{TK}^{-}\right) \mathrm{Cl} \mathrm{ID}$ cells results in their capacity to incorporate thymidine and 5-bromodeoxyuridine (BrdU) into mitochondrial DNA (mit-DNA) at a substantial rate, in the absence of any significant incorporation of these precursors into nuclear DNA. Furthermore, these cells can be grown indefinitely in the dark in the presence of $\mathrm{BrdU}(30 \mu \mathrm{g} / \mathrm{ml})$. These properties of $\mathrm{LM}\left(\mathrm{TK}^{-}\right) \mathrm{Cl}_{\mathrm{ID}}$ cells provide a valuable tool for studying the photosensitizing, miscoding and mutagenic effects of this halogenated precursor which depend on its incorporation into the organelle DNA, in the absence of nuclear effects. We report here the results of experiments indicating that growth in the presence of $30 \mu \mathrm{g} / \mathrm{ml} \mathrm{BrdU}$ confers upon $\mathrm{LM}\left(\mathrm{TK}^{-}\right) \mathrm{Cl}$ ID cells an increased sensitivity to 'visible' light and an increased thermotolerance, as compared to those of cells grown in the absence of BrdU. In the accompanying paper (Croizat \& Attardi, 1975), evidence is presented indicating that, during 'visible' light irradiation of $\mathrm{LM}\left(\mathrm{TK}^{-}\right) \mathrm{Cl}_{\mathrm{I}} \mathrm{D}$ cells grown in the presence of BrdU, progressive damage and destruction of mit-DNA occur, and these are probably responsible for the loss of viability of these cells.

\section{MATERIALS AND METHODS}

\section{Cells and methods of growth}

The cell lines were grown attached to plastic Petri dishes or tissue culture bottles (Falcon plastic) in Eagle's medium, or in spinners in modified Eagle's medium (Levintow \& Darnell, I 960), in both cases with $10 \%$ calf serum. The $\mathrm{LM}\left(\mathrm{TK}^{-}\right) \mathrm{Cl} \mathrm{ID}$ cell line was grown in the dark (except in the irradiation experiments) in the presence or absence of $30 \mu \mathrm{g} / \mathrm{ml} \mathrm{BrdU}$, as specified below. In the experiments utilizing cells growing in the absence of BrdU, this precursor was removed from the medium at least 10 days earlier. The A9 cell line, an $\mathrm{L}$ cell derivative resistant to 8-azaguanine and deficient in hypoxanthine-guanine phosphoribosyltransferase (Littlefield, 1964) was grown in the presence of $3 \mu \mathrm{g} / \mathrm{ml} 8$-azaguanine. In order to label with BrdU the DNA of A9 cells, plates containing about $5 \times 10^{3}$ cells were covered with $10 \mathrm{ml}$ of medium containing $30 \mu \mathrm{g} / \mathrm{ml} \mathrm{BrdU}$ and incubated for up to 3 days in the dark.

Handling of both $\mathrm{Cl}$ ID and A9 cells grown in the presence of BudR was always carried out in a hood with dim light. The cell lines used were free of any detectable PPLO contamination, as revealed by the method of Brown, Teplitz \& Revel (1974).

\section{Labelling conditions}

In order to compare the incorporation of $\left[\mathrm{Me}^{3} \mathrm{H}\right]$ thymidine into nuclear DNA of $\mathrm{Cl}$ ID and $\mathrm{Ag}$ cells, a spinner culture of each of the 2 cell lines ( $\mathrm{Cl}$ ID in the absence of $\mathrm{BrdU}$ ) at about $10^{5}$ cells $/ \mathrm{ml}$ was labelled for approximately 2 generations with $\left[2-{ }^{14} \mathrm{C}\right]$ thymidine $(8.5 \mu \mathrm{Ci} / \mu \mathrm{M} ; 0.055 / \mu \mathrm{Ci} / \mathrm{ml})$. 


\section{Irradiation experiments}

Exposure of the cells to 'visible' light was carried out either at a high or at a low density. In the first case, $3-7 \times 10^{5}$ cells were plated in $40-\mathrm{ml}$ plastic tissue culture bottles with $10 \mathrm{ml}$ Eagle's medium plus 10\% calf serum (supplemented with BrdU or 8 -azaguanine, when so indicated). In the irradiation experiments at low cell density, about 200 or 2000 cells were plated in the same size plastic bottles with Io-ml Eagle's medium plus $20 \%$ calf serum (supplemented with BrdU or 8-azaguanine if so required). In both types of experiments, the bottles were kept for $20-24 \mathrm{~h}$ (unless otherwise specified) in the $37^{\circ} \mathrm{C}$ incubator. After changing the medium with $10 \mathrm{ml}$ of the same medium (except when otherwise indicated), cultures were illuminated, in a $37{ }^{\circ} \mathrm{C}$ room, for different times with 2 fluorescent lamps $(40-\mathrm{W}$, Westinghouse Cool White tubes, $120 \mathrm{~cm}$ long) mounted $10 \mathrm{~cm}$ apart and at a distance of $10 \mathrm{~cm}$ from the bottles, as described by Puck \& Kao (1967). Other plates were covered with aluminium foil and placed close to the illuminated ones as non-irradiated controls. A fan ensured that the temperature near the bottles did not exceed $37^{\circ} \mathrm{C}$. At various times, the low cell density cultures were transferred to a $37^{\circ} \mathrm{C}$ incubator, while the high cell density cultures were trypsinized, plated at appropriate cell concentrations in $100-\mathrm{cm}^{2}$ square Petri dishes with $\mathrm{I} 0 \mathrm{ml}$ of the same medium used during irradiation (unless otherwise specified), supplemented, however, with $20 \%$ calf serum, and then transferred into a $37^{\circ} \mathrm{C}$ incubator. After $7-10$ days, the colonies were stained with May-Greenwald and Giemsa and scored. The plating efficiency of unirradiated cells grown either in the presence or absence of BudR was, under the present conditions, about $80 \%$.

\section{Thermoresistance experiments}

Cells to be exposed to a higher than normal temperature were plated at about $7 \times 10^{5}$ cells $/$ dish in $10-\mathrm{cm}$ plastic Petri dishes in $10 \mathrm{ml}$ Eagle's medium (with or without $30 \mu \mathrm{g} / \mathrm{ml} \mathrm{BrdU}$ ) supplemented with ro \% calf serum, and kept in a $37^{\circ} \mathrm{C}$ incubator. Twenty-four hours later, the cultures were fluid changed and transferred into an incubator adjusted to $39 \pm 0.3{ }^{\circ} \mathrm{C}$ or $40 \pm 0.3{ }^{\circ} \mathrm{C}$. Control cultures, after fluid change, were kept at $37^{\circ} \mathrm{C}$. At different times, the cultures were trypsinized, plated at appropriate concentrations in $100-\mathrm{cm}^{2}$ square Petri dishes with $10 \mathrm{ml}$ of the same medium used during the previous incubation, and then incubated at $37^{\circ} \mathrm{C}$ for cloning efficiency determinations.

\section{Extraction and analysis of total cell DNA}

The DNA from $\mathrm{Cl}$ i D and $\mathrm{A} 9$ cells, labelled with $\left[2_{-14}{ }^{14} \mathrm{C}\right]$ thymidine as described above, was extracted essentially according to the procedure of Marmur (I96r), with the modification that 2 phenol-sodium dodecylsulphate deproteinization steps were carried out after the pancreatic RNase digestion. Buoyant density analysis of the DNA was carried out in a $\mathrm{CsCl}$ densitygradient by using a $\mathrm{CaCl}$ solution of density of $\mathrm{I} 708 \mathrm{~g} \mathrm{~cm}^{-3}$ and centrifuging in a Spinco $6_{5}$ fixed-angle rotor at $40000 \mathrm{rev} / \mathrm{min}$ for $67 \mathrm{~h}$. After dropwise collection of the gradient, the fractions were diluted with $\mathrm{I} \cdot 0 \mathrm{ml} \mathrm{IO}^{-2} \mathrm{M}$ Tris buffer, $\mathrm{pH} 7.4\left(25{ }^{\circ} \mathrm{C}\right)$, $10^{-2} \mathrm{M}$ EDTA, their O.D.200 was measured and the trichloroacetic acid-precipitable radioactivity determined on an aliquot of each sample.

\section{RESULTS}

Effects of irradiation with 'visible' light on clone-forming ability of BrdU-grown and control* $C l$ i $D$ cells plated at low cell density

Fig. I shows the effects of 'visible' light irradiation on the cloning efficiency of control and BrdU-grown $\mathrm{Cl} I \mathrm{D}$ cells, plated at low cell density in the absence or

- Unless otherwise specified, the term 'control' is used in this paper to indicate cells grown in the absence of BrdU. 
presence of the halogenated precursor, respectively. The irradiated control $\mathrm{Cl} \mathrm{ID}_{\mathrm{D}}$ cells exhibited, after a lag of $6-8 \mathrm{~h}$, an exponential loss of cloning efficiency with a half-life of 2-3 h. The BrdU-grown cells showed a shorter lag and a somewhat faster loss of cloning efficiency.

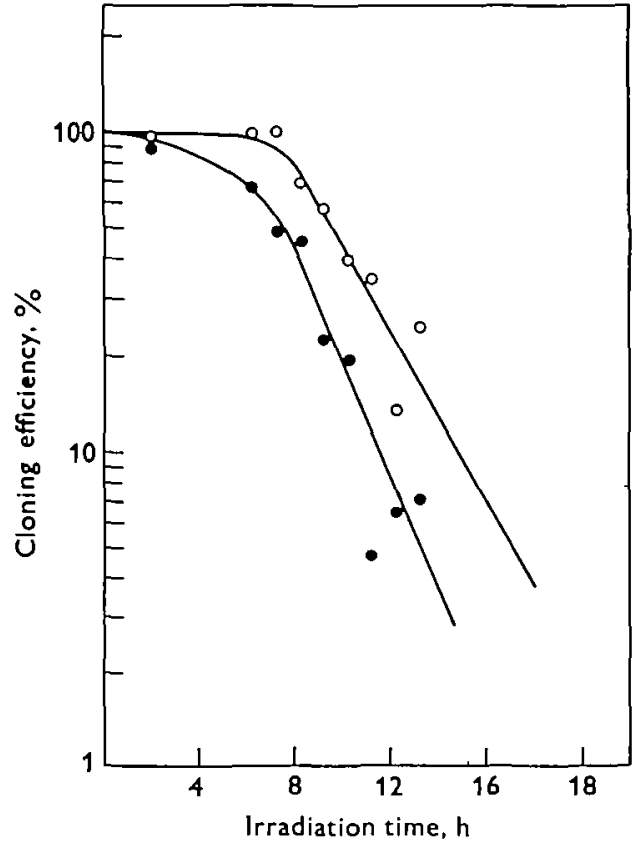

Fig. I

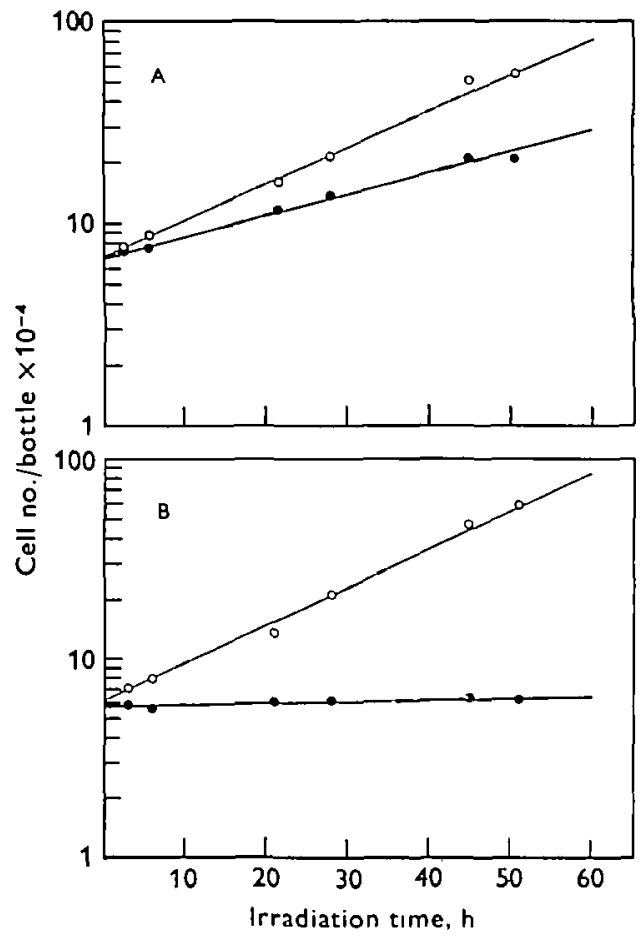

Fig. 2

Fig. I. Cloning efficiency of BrdU-maintained (O) and control LM(TK-) Cl ID cells $(O)$ irradiated with 'visible' light for different lengths of time. Forty-millilitre plastic bottles seeded with 200 cells in $10 \mathrm{ml}$ medium were exposed to 'visible' light under the conditions described in Materials and methods. After illumination, the cultures were incubated in the dark for 8 days, and the colonies then stained with May-Greenwald and Giemsa.

Fig. 2. Growth curves of control (A) and BrdU-maintained (B) $\mathrm{LM}\left(\mathrm{TK}^{-}\right) \mathrm{Cl}_{\text {I }} \mathrm{D}$ cells which were exposed to 'visible' light or kept in the dark. Forty-millilitre plastic bottles were seeded each, in different series, with 6 or $7 \times 10^{5}$ cells in ro ml medium without (A) or with (B) BrdU, and, after $24 \mathrm{~h}$ in a $37^{\circ} \mathrm{C}$ incubator, either illuminated with 'visible' light for different periods of time $(\Theta)$ or covered with aluminium foil $(O)$ and placed close to the illuminated cultures. At various times, the cultures were trypsinized and counted.

Effects of irradiation with 'visible' light on growth rate and clone-forming ability of $B r d U$-grown and control $C l$ I $D$ cells plated at high cell density

Fig. 2 shows the growth curves of control and BrdU-grown cultures during 'visible' light irradiation in the absence or presence of the halogenated precursor, respectively. The non-irradiated cultures, either in the presence or absence of $\mathrm{BrdU}$, grew with a generation time of about $\mathrm{I} 6 \mathrm{~h}$, while the irradiated control $\mathrm{Cl}$ ID cells went through 
only $\mathrm{I} \cdot 5$ generations in $50 \mathrm{~h}$ (apparent generation time of about $3 \circ \mathrm{h}$ ). In the experiment shown in Fig. 2, the irradiated BrdU-grown $\mathrm{Cl}$ ID cells barely showed a 10\% increase in cell number during the same time. In other experiments of the same type, however, the $\mathrm{BrdU}$-grown $\mathrm{Cl}$ I D cells showed a higher increase in cell number during irradiation, up to one doubling in about $50 \mathrm{~h}$, approaching the growth rate of the irradiated control $\mathrm{Cl}$ ID cells.
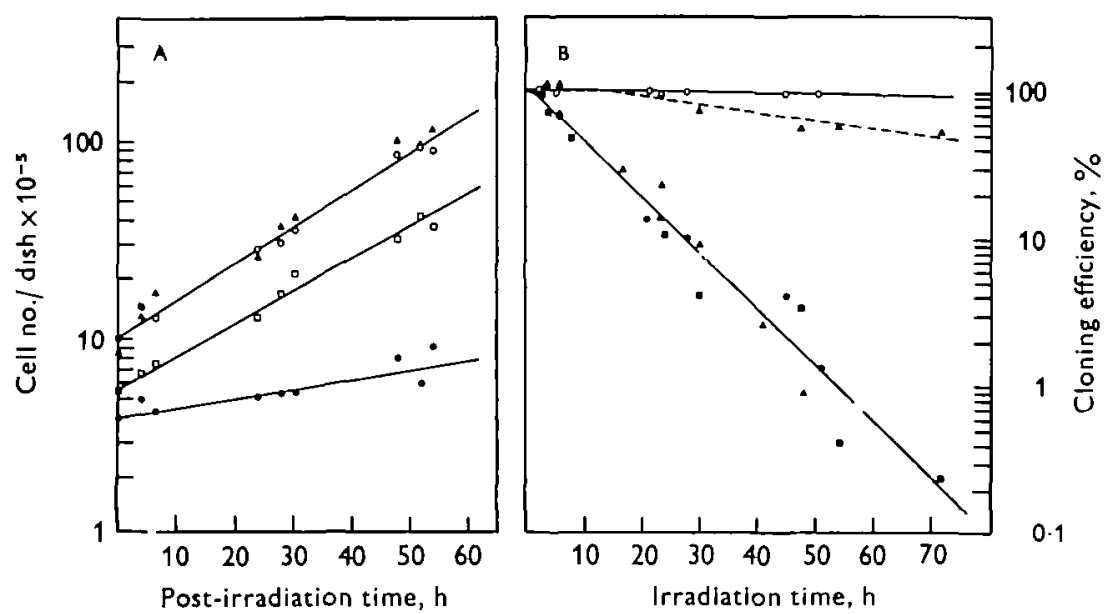

Fig. 3. A, growth curves of BrdU-maintained and control $\mathrm{LM}\left(\mathrm{TK}^{-}\right) \mathrm{Cl}$ ID cells, which had been exposed to 'visible' light ( $\bigcirc$ and $\square$, respectively) or kept in the dark for $60 \mathrm{~h}$ ( $\Delta$ and $O$, respectively), and then trypsinized and replated for mass growth measurements. B, cloning efficiency of BrdU-maintained and control $\mathrm{LM}\left(\mathrm{TK}^{-}\right) \mathrm{Cl}$ ID cells $(\boldsymbol{O}, \boldsymbol{\Delta}, \mathbf{\square}$ and $O, \Delta$, respectively), which had been exposed to 'visible' light or kept in the dark for different periods of time, and then trypsinized and replated at appropriate concentrations in $100-\mathrm{cm}^{2}$ square Petri dishes for cloning efficiency determinations. The data of 3 separate experiments are indicated by different symbols.

A striking difference in growth rate and cloning efficiency between irradiated control and irradiated BrdU-grown cells was, on the other hand, consistently observed when the irradiated cultures were first trypsinized and then plated, at high or low cell density, in the absence or presence of BrdU, respectively. As appears in Fig. $3 \mathrm{~A}$, the control $\mathrm{Cl}$ I D cells irradiated for $60 \mathrm{~h}$, then trypsinized and replated at high cell density, grew at a rate only very slightly lower than the non-irradiated, trypsinized cells (generation time of about $\mathrm{I} 8 \mathrm{~h}$ ). By contrast, the $60 \mathrm{~h}$-irradiated and trypsinized BrdU-grown $\mathrm{Cl} I \mathrm{D}$ cells grew at an extremely reduced rate, with an apparent generation time of more than $60 \mathrm{~h}$. This difference in behaviour between irradiated control and BrdU-grown cells after trypsinization was also observed when the cloning efficiency of the 2 types of cultures was analysed. In fact, the irradiated and trypsinized control $\mathrm{Cl}$ ID cells showed a very slow, if any, decline in cloning efficiency during a 70-h irradiation (Fig. $3^{\mathrm{B}}$ ). On the contrary, the irradiated and trypsinized BrdUgrown $\mathrm{Cl}$ ID cells exhibited, with a very short, if any, lag, a fairly rapid exponential decline of cloning efficiency with a half-life of about $8 \mathrm{~h}$ down at least to $0 . \mathrm{I} \%$ survival (Fig. $3^{\mathrm{B}}$ ). 
The question of whether the photosensitivity was due to the exposure of the cells to BrdU prior to irradiation, or to the halogenated precursor being present in the medium during irradiation, was investigated by carrying out experiments of irradiation of BrdU-grown cells in BrdU-free medium. As appears in Fig. 4, under these conditions, the irradiated and trypsinized BrdU-grown cells showed an exponential decline of cloning efficiency with about twice as long half-life (about $\mathrm{I} 8 \mathrm{~h}$ ) as observed in the irradiation experiments in the presence of BrdU; this was still a much faster loss of clone-forming ability than observed with irradiated and trypsinized control $\mathrm{Cl}$ ID cells (Fig. $3 \mathrm{~B})$.

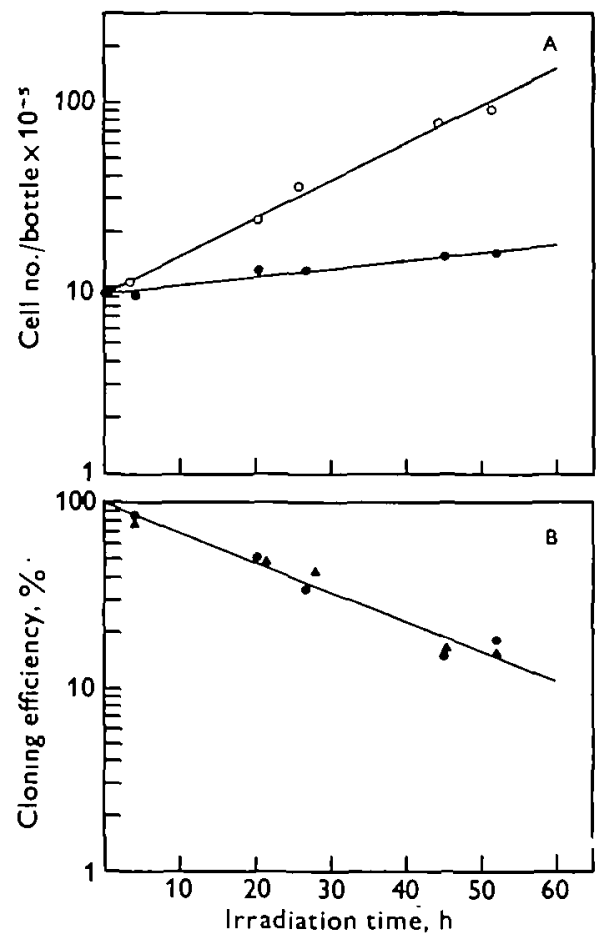

Fig. 4, A, growth curves of $\mathrm{BrdU}$-maintained $\mathrm{LM}\left(\mathrm{TK}^{-}\right) \mathrm{Cl}$ I D cells which were exposed to 'visible' light $(\bigcirc)$ or kept in the dark $(O)$ in medium without BrdU. B, the cultures which had been irradiated or kept in the dark in the experiment shown in A and in a similar experiment were trypsinized and replated at appropriate concentrations in Petri dishes in BrdU-containing medium for cloning-efficiency determinations.

Effects of irradiation with 'visible' light on clone-forming ability of BrdU-grown and control A9 cells

In order to compare the effects of 'visible' light irradiation on the clone-forming ability of BrdU-grown $\mathrm{Cl} \times \mathrm{D}$ cells with the effects of such irradiation on cells which have incorporated BrdU into nuclear DNA to a substantial extent, Ag cells, which have normal extramitochondrial thymidine kinase activity (Attardi \& Attardi, 1972), were grown for 2 or 3 cell generations ( 48 or $72 \mathrm{~h}$, respectively) in the presence of $30 \mu \mathrm{g} / \mathrm{ml} \mathrm{BrdU}$, and then subjected to irradiation at low cell density. As appears from the inset in Fig. 5, in the presence of the halogenated precursor, A9 cells went 
through more than two generations of growth with a normal generation time (about $24 \mathrm{~h}$ ), and then stopped growing. Irradiation of these cells caused, after a short lag, a rapid exponential loss of cloning efficiency, with a half-life of about 4 and $5 \mathrm{~min}$, respectively, for cells grown for 2 and 3 generations in the presence of $\operatorname{BrdU}$.

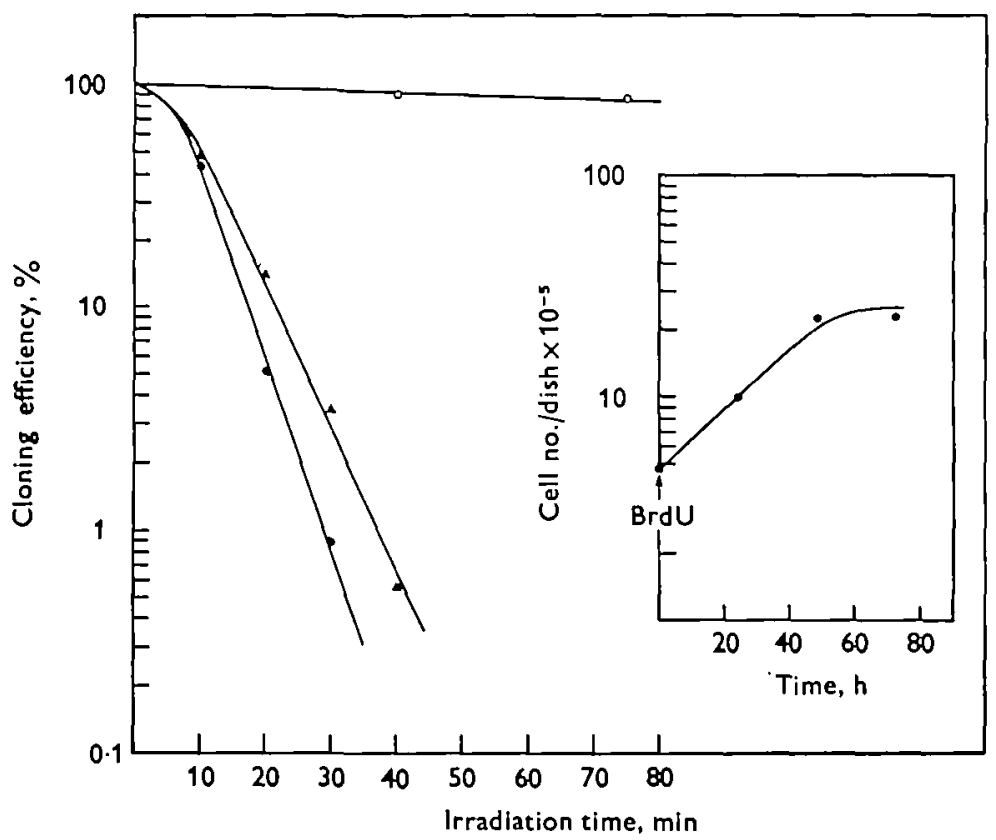

Fig. 5. Effect of 'visible' light irradiation on the cloning efficiency of Ag cells grown in the presence of BrdU for 2 or 3 generations or in the absence of BrdU. A9 cells, grown for 2 or 3 days ( $\Delta$ or $\boldsymbol{O}$, respectively) in the dark in medium containing $3 \mu \mathrm{g} / \mathrm{ml} \mathrm{8-azaguanine}$ and $30 \mu \mathrm{g} / \mathrm{ml} \mathrm{BrdU}$ (see growth curve in inset), or in medium supplemented with 8-azaguanine but without BrdU $(O)$, were trypsinized and plated at suitable concentrations in $40-\mathrm{ml}$ plastic bottles with ro $\mathrm{ml}$ of the same medium used during the previous growth. After $7 \mathrm{~h}$ in a $37^{\circ} \mathrm{C}$ incubator, the bottles were exposed to 'visible' light for different lengths of time, then transferred back to the $37^{\circ} \mathrm{C}$ incubator and the colonies stained after ro days.

To obtain an estimate of the level of possible incorporation of BrdU into nuclear DNA of $\mathrm{Cl}$ I D cells due to residual extramitochondrial thymidine kinase activity, the incorporation of labelled thymidine into total cell DNA was compared in A9 cells and $\mathrm{Cl}$ ID cells. In previous work (Attardi \& Attardi, 1972), the incorporation of $\left[M e-{ }^{3} \mathrm{H}\right]$ thymidine into nuclear DNA of $\mathrm{Cl} \mathrm{I} \mathrm{D}$ cells was estimated to be less than I $\%$ of that in A9 cells. A more accurate determination was made in the present work by using $\left[2{ }^{14} \mathrm{C}\right]$ thymidine as a labelled precursor and by paying attention to avoiding exhaustion of the isotope in the medium. Fig. 6 shows the density profile in $\mathrm{CsCl}$ gradients of total DNA extracted from cells grown for 2 generations in the presence of $\left[2-{ }^{14} \mathrm{C}\right]$ thymidine. The non-symmetrical aspect of the profiles reflects an artifact of collection due to the viscosity of the DNA, which had to be loaded on to the gradient in relatively large amounts to allow detection of the low level of labelling in $\mathrm{Cl}$ I D 
cells. For the same reason, no resolution of mitochondrial and nuclear DNA was obtained in these gradients. After correction for the small difference in fractional increase of total cell mass during growth of the 2 cell populations, the specific activity of total DNA from $\mathrm{Cl}$ ID cells was found to be $0.34 \%$ of that of total DNA from Ag cells.

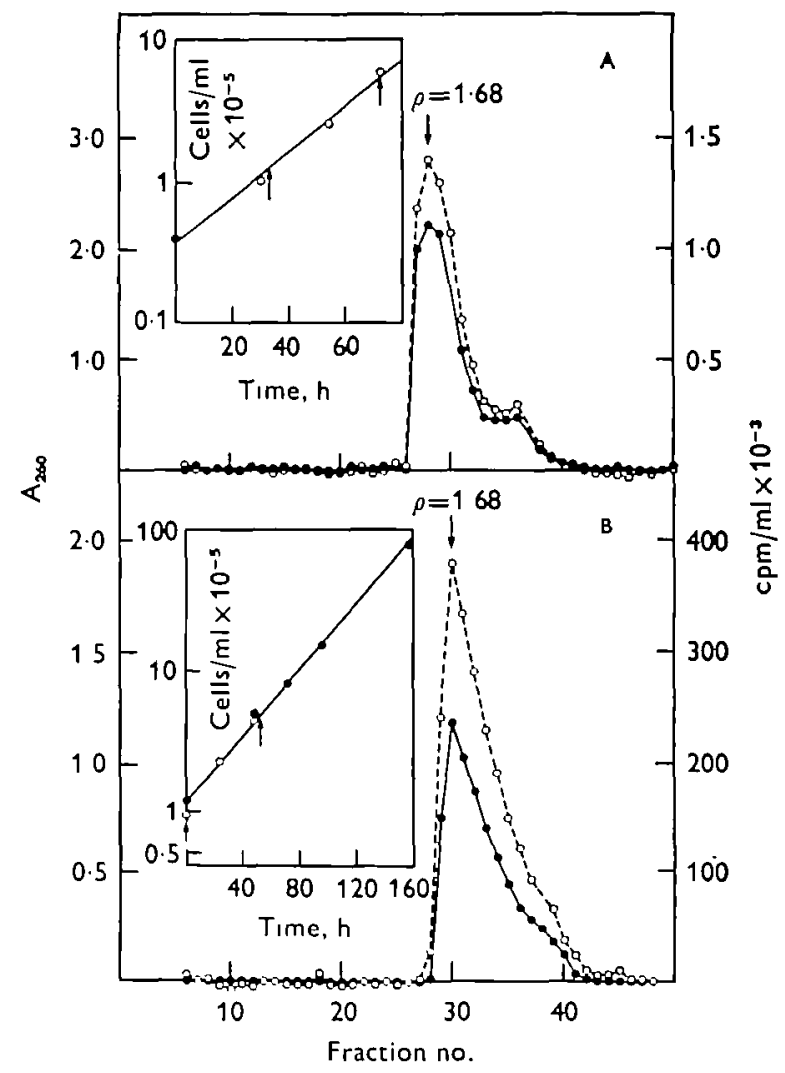

Fig. 6. Long-term incorporation of $\left[2{ }^{14} \mathrm{C}\right]$ thymidine into total cell DNA of $\mathrm{LM}(\mathrm{TK}-)$ $\mathrm{Cl}_{\text {I }} \mathrm{D}(\mathrm{A})$ and $\mathrm{A}_{9}$ cells (B). Total cell DNA was extracted from $\mathrm{LM}\left(\mathrm{TK}^{-}\right) \mathrm{Cl}_{\mathrm{I}} \mathrm{D}$ cells and A9 cells grown in spinners for approximately two generations in BrdU-free medium in the presence of $\left[2-{ }^{14} \mathrm{C}\right]$ thymidine, and analysed in $\mathrm{CsCl}$ density gradients. The insets show the growth curves of the cultures utilized, and the arrows indicate the time of addition of $\left[2-{ }^{14}\right]$ thymidine and the time of cell harvesting (in the inset of B the growth curves of the culture used for labelling and of a parallel unlabelled culture are shown). $\mathrm{O}---\mathrm{O}, \mathrm{A}_{260} ; 0-0,{ }^{14} \mathrm{C} \mathrm{cpm}$.

\section{Nature of the reversible 'killing' by 'visible' light of control $C l$ i $D$ cells}

The nature of the reversible killing by 'visible' light of control $\mathrm{Cl} \mathrm{ID} \mathrm{cells} \mathrm{was}$ further investigated. Cutting off, by a $\mathrm{I}-\mathrm{cm}$ thick solution of $\mathrm{I} \mathrm{mg} / \mathrm{ml}$ thymine, of any possible ultraviolet components in the $250-280 \mathrm{~nm}$ range present in the 'visible' light used for irradiation did not reduce the killing effects (Fig. 7): this would tend to exclude any direct damage of cell DNA by ultraviolet during irradiation. Repeated changes of the medium during irradiation had likewise no influence (Fig. 7): this 


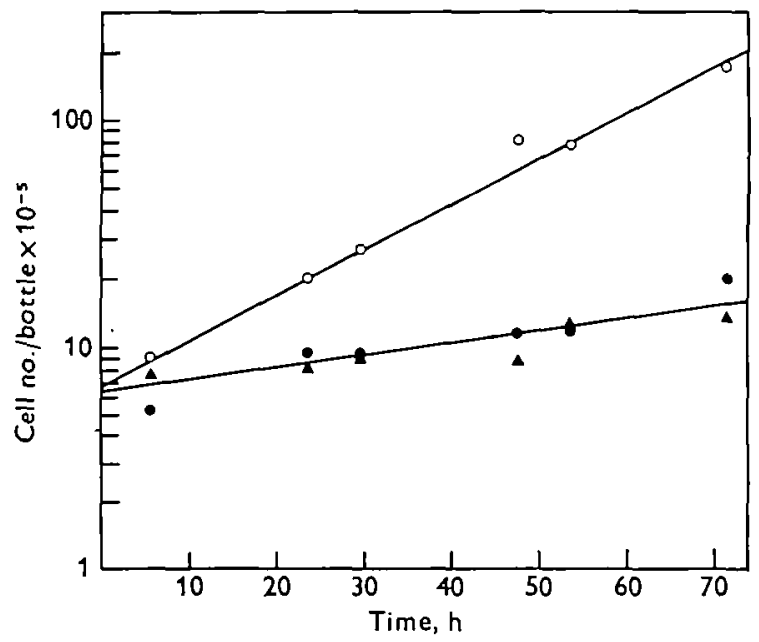

Fig. 7. Failure to affect the reversible killing by 'visible' light of control LM(TK-) $\mathrm{Cl}$ I D cells (maintained in BrdU-free medium) by means of repeated changes of the medium during irradiation or by cutting off any $250-280 \mathrm{~nm}$ components in the 'visible' light. Cultures, prepared as described in the legend of Fig. 2 in BrdU-free medium, were either exposed for different periods of time to 'visible' light from which the $250-280 \mathrm{~nm}$ components had been cut off by a I-cm-thick I $\mathrm{mg} / \mathrm{ml}$ thymine solution (-), or irradiated with unfiltered 'visible' light with frequent (every $12 \mathrm{~h}$ ) changes of the medium $(\boldsymbol{\Delta})$. Parallel cultures were completely shielded from light with aluminium foil $(O)$.

result would argue against an accumulation of toxic photoproducts in the medium as being responsible for the reversible killing effect.

\section{Thermoresistance of $B r d U_{\text {-grown }} \mathrm{Cl}$ I $D$ cells}

The growth of BrdU-maintained and control $\mathrm{Cl}$ ID cells was measured at different temperatures, in the presence or absence of BrdU, respectively. As appears in Fig. 8, at $37^{\circ} \mathrm{C}$, both $\mathrm{BrdU}$-maintained and control $\mathrm{Cl}$ ID cells grew with a generation time of about $\mathrm{I} 5 \mathrm{~h}$. At $39^{\circ} \mathrm{C}$, the generation time was somewhat increased (to about I $8 \mathrm{~h}$ ) for both BrdU-maintained and control $\mathrm{Cl}$ ID cells (not shown). At $40^{\circ} \mathrm{C}$, the control cultures went through only one generation of growth in about $20 \mathrm{~h}$, then stopped growing and started disintegrating; by contrast, at the same temperature, the BrdU-maintained cells grew at a decreasing rate for 2 generations. These results suggested that growth in the presence of BrdU had conferred upon $\mathrm{Cl}$ ID cells an increased thermoresistance. This interpretation was confirmed by the analysis of cloning efficiency of $\mathrm{Cl} \times \mathrm{D}$ cells which had been grown for various lengths of time at different temperatures. As appears in Fig. 9, no loss of clone-forming ability was observed for either BrdU-grown or control $\mathrm{Cl}$ I D cells during growth at $37^{\circ} \mathrm{C}$ or $39^{\circ} \mathrm{C}$. A loss of cloning efficiency was, on the contrary, observed during growth at $40^{\circ} \mathrm{C}$ of both $\mathrm{BrdU}$-maintained and control $\mathrm{Cl}$ ID cells: this loss of viability was reproducibly more rapid for the control cells. In particular, the cloning efficiency of control $\mathrm{Cl}$ ID cells decreased slowly during the first $30 \mathrm{~h}$ to about $50 \%$; thereafter, 


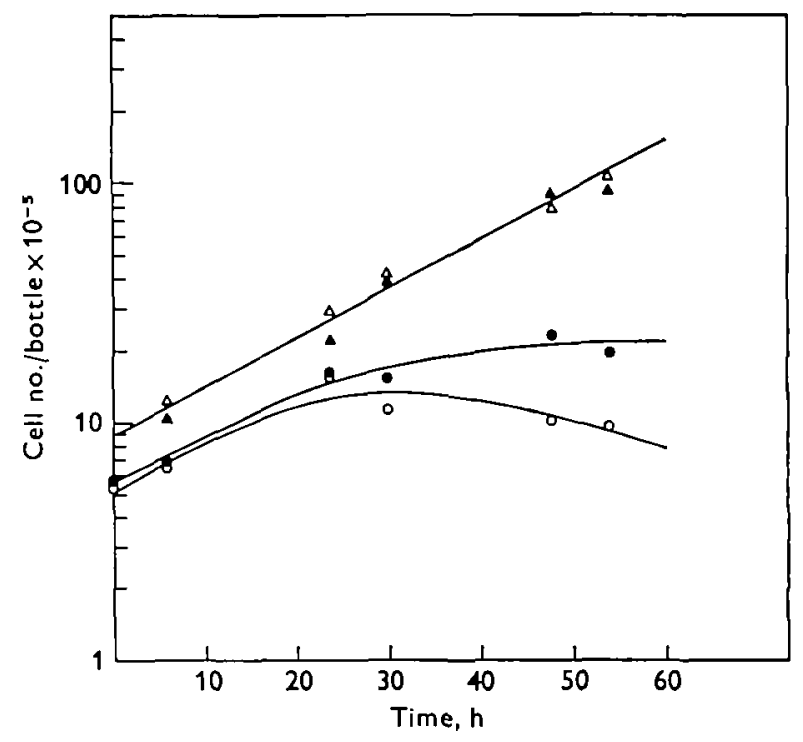

Fig. 8. Growth curves at 37 and at $40^{\circ} \mathrm{C}$ of control ( $\triangle$ and $O$, respectively) and BrdUmaintained ( $\Delta$ and - , respectively) $\left.\mathrm{LM}_{(\mathrm{TK}}{ }^{-}\right) \mathrm{Cl}$ I D cells. See Materials and methods for experimental details.

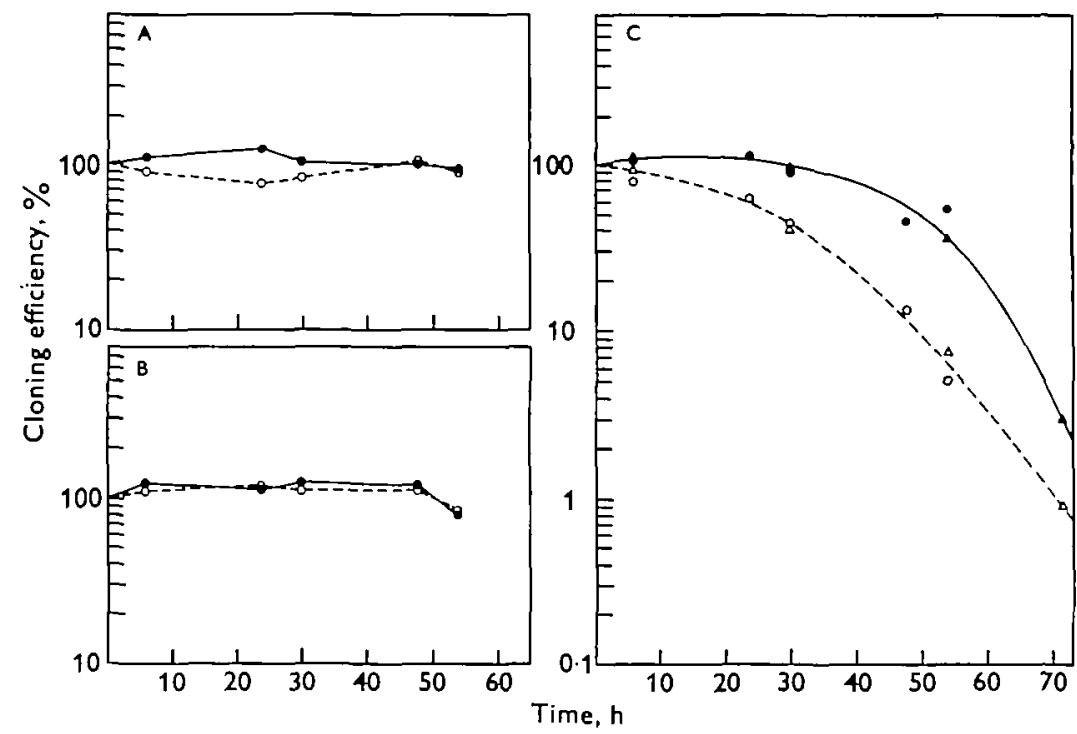

Fig. 9. Cloning efficiency of control (hollow symbols) and BrdU-maintained LM(TK-) $\mathrm{Cl}$ ID cells (solid symbols) after different periods of growth at 37,39 or $40^{\circ} \mathrm{C}(\mathrm{A}, \mathrm{B}, \mathrm{C}$, respectively). Cultures which had been grown at different temperatures for various periods of time were trypsinized and plated at appropriate concentrations in $100-\mathrm{cm}^{3}$ square Petri dishes, and then incubated at $37^{\circ} \mathrm{C}$ for cloning efficiency determinations. The data of 2 separate experiments are indicated by different symbols. 
the loss of viability accelerated to a rate corresponding to a half-life of about $7 \mathrm{~h}$. By contrast, BrdU-grown cells did not exhibit any loss of cloning efficiency during the first $30-40 \mathrm{~h}$; thereafter, the loss of viability proceeded at the same rate as in control cells. After $55 \mathrm{~h}$ of growth at $40^{\circ} \mathrm{C}$, only $5-7 \%$ of the control cells and by contrast $40-60 \%$ of the BrdU-grown cells survived.

\section{DISCUSSION}

\section{$B r d U$-independent damage of $C l_{\text {I }} D$ cells by 'visible' light}

Irradiation with visible light of $\mathrm{Cl}{ }_{\mathrm{I}} \mathrm{D}$ cells grown either in the presence or absence of BrdU causes a loss of viability, which results in a marked slowing down of the growth rate of mass cultures and in a fairly fast exponential decline of cloning efficiency, with a half-life of $2-3 \mathrm{~h}$, after a lag of 6-8 h. This loss of viability does not appear to be caused by damage to the cell DNA by ultraviolet components in the $250-280 \mathrm{~nm}$ range present in the 'visible' light used for irradiation, nor by accumulation in the medium of toxic photoproducts. That the damage involves some block in mitosis is strongly suggested by the observation, to be reported in the accompanying paper (Croizat \& Attardi, 1975), that there is during irradiation a substantial increase in average cell volume, up to the doubling of the original size. A striking, as yet unexplained phenomenon is the fact that this BrdU-independent damage by 'visible' light is to a great extent reversible as a result of the trypsinization of the culture and transfer of the cells to fresh medium.

Specific effects of 'visible' light irradiation on growth rate and cloning efficiency of BrdUgrown $C l$ i $D$ cells

Superimposed upon the BrdU-independent damage caused by 'visible' light irradiation are the specific effects that such irradiation has on BrdU-grown cells. Such specific effects can better be studied if the irradiated cultures are trypsinized and transferred, either for mass growth or for cloning experiments, so as to minimize the non-specific damage due to irradiation. The loss of cloning efficiency which one can detect under such conditions proceeds according to simple exponential kinetics, without any significant lag and with a half-life of about $8 \mathrm{~h}$ down at least to $0 . \mathrm{I} \%$ survival.

\section{Nature of BrdU-dependent damage by 'visible' light}

The loss of viability induced by 'visible' light on BrdU-grown cells does not depend on the presence of $\mathrm{BrdU}$ in the medium during irradiation. Therefore, it is unlikely that it is due to some damaging effects of free $\mathrm{Br}$ radicals in the medium; rather, the data indicate that the damage depends on the previous exposure of the cells to the halogenated precursor.

The possibility that the loss of viability of $\mathrm{Cl} I \mathrm{D}$ cells results from damage by 'visible' light of nuclear DNA, due to residual incorporation of BrdU into this DNA, was investigated by comparing the relative sensitivity to 'visible' light irradiation of 
BrdU-grown $\mathrm{Cl}$ ID cells and $\mathrm{BrdU}$-grown $\mathrm{A9}$ cells, a cell line with normal extramitochondrial thymidine kinase activity (Attardi \& Attardi, 1972), with the relative extent of incorporation of the halogenated precursor into their nuclear DNA. Ag cells which had been grown for 2 or 3 generations in the presence of $30 \mu \mathrm{g} / \mathrm{ml} \mathrm{BrdU}$ showed a sensitivity to 'visible' light irradiation about 100 times higher than that of BrdUgrown $\mathrm{Cl}$ I D cells. An estimate of the possible residual incorporation of $\mathrm{BrdU}$ into nuclear DNA of $\mathrm{Cl}_{I} \mathrm{D}$ cells relative to the incorporation in $\mathrm{A}_{9}$ cells was obtained from the comparison of the capacity of $\mathrm{Cl}$ ID cells and $\mathrm{A} 9$ cells to incorporate $\left[\mathrm{Me}^{-}{ }^{3} \mathrm{H}\right]-$ thymidine into total cell DNA in a long-term labelling experiment. This comparison showed that the level of $\left[\mathrm{Me}^{3} \mathrm{H}\right]$ thymidine incorporation into total cell DNA of $\mathrm{Cl}$ ID cells was about $0.3 \%$ of that into A9 cells. Since $0.1-0.2 \%$ of total cell DNA in these $\mathrm{L}$ cell derivatives is presumably represented by mitochondrial DNA, as in the parental L cells (Nass, 1969; Bogenhagen \& Clayton, 1974), it is reasonable to conclude that the possible residual incorporation of $\mathrm{BrdU}$ into nuclear $\mathrm{DNA}$ of $\mathrm{Cl}$ ID cells is at most $0 . \mathrm{I}-0.2 \%$ of that measured in A9 cells. This level is 5-IO times lower than that which could account for the observed sensitivity of $\mathrm{Cl}$ ID cells to 'visible' light irradiation, assuming a random residual incorporation of $\mathrm{BrdU}$ into nuclear DNA and a linear relationship between sensitivity to light and degree of thymine substitution by BrdU, as in phage DNA (Fox \& Meselson, 1963).*

The present results are, on the contrary, compatible with the idea that the loss of viability of $\mathrm{BrdU}$-grown $\mathrm{Cl}$ I D cells during irradiation is due to damage of mit-DNA, which incorporates BrdU at a comparable rate in these cells and in A9 cells (Attardi \& Attardi, 1972). The single-hit shape of the curve illustrating the loss of cloning efficiency of irradiated BrdU-grown $\mathrm{Cl}$ ID cells is not in disagreement with this interpretation. In fact, a similar situation has been described in yeast, where petite induction by a variety of agents, like heat (Sherman, 1959), acriflavine (Sugimura, Okabe \& Imamura, 1966), ethidium bromide (Slonimski, Perrodin \& Croft, 1968), and ultraviolet irradiation (Wilkie, 1963 ; Maroudas $\&$ Wilkie, I 968 ), has been found to follow first-order kinetics with an estimated number of targets varying between I and 6, i.e. much smaller than the number of mit-DNA molecules per cell (about $5^{\circ}$ (Williamson, 1970; Nagley \& Linnane, 1972)). The reason for this behaviour is still unknown.

The idea that BrdU-substituted mit-DNA is the target of the killing action of 'visible' light is also compatible with the previously discussed results indicating that BrdU-grown $\mathrm{Cl} \mathrm{rD}$ cells lose their cloning efficiency, when exposed to light, at about one-half the normal rate if the medium utilized during irradiation does not contain BrdU. In fact, during the first $\mathrm{io} h$ of irradiation of $\mathrm{Cl} \mathrm{ID}$ cells, besides a moderate increase in their number, there is an approximate $50 \%$ increase in their average size (see accompanying paper); therefore, if the intact mit-DNA molecules

- For the low level of thymine substitution by BrdU which may occur in nuclear DNA of $\mathrm{Cl}$ I D cells (corresponding to I or $2 \mathrm{BrdU}$ residues for 2000 total nucleotides, if the substitution in A9 cells is taken as $50 \%$ (Djordjevic \& Szybalski, I 960; Flory \& Vinograd, 1973)), it seems likely that the photosensitivity of $\mathrm{Cl}$ ID cells which may be due to nuclear effects would be less than expected on the basis of this linear relationship, because of the diploid or higher complement of genes. 
continue to replicate during irradiation in proportion to the cell mass increase, at least one-half of them will undergo in $10 \mathrm{~h}$ one cycle of replication, being converted (in the absence of significant precursor pool effects) to heavy-light hybrid molecules. Depending on the assumptions one is willing to make concerning the effects on mitDNA replication of the photochemical damage in each of the two strands, BrdUthymine hybrid DNA molecules could be expected to have a sensitivity to 'visible' light intermediate between that of heavy-heavy and that of light-light molecules, or consist of half-sensitive, half-resistant molecules. On the basis of these considerations, it is reasonable to assume that, after $10 \mathrm{~h}$ irradiation (corresponding to about $50 \%$ cell survival; see Fig. 3 B), the majority of the mit-DNA molecules still undamaged at that time will be BrdU-thymine hybrids. Consequently, the sensitivity to visible light of the $50 \%$ survivors will approach that of cells containing exclusively hybrid mit-DNA molecules, and the more so, the longer the irradiation time.

In the accompanying paper (Croizat \& Attardi, I975), evidence will be presented indicating that, in BrdU-grown $\mathrm{Cl} I \mathrm{D}$ cells, 'visible' light irradiation produces specific destruction of mit-DNA at a rate which would account reasonably well for the loss of viability of these cells.

\section{Effect of $B r d U$ incorporation on heat resistance of $C l$ I $D$ cells}

The increased thermoresistance of $\mathrm{BrdU}$-grown $\mathrm{Cl} \mathrm{ID}$ cells observed here indicates an effect of $\mathrm{BrdU}$ incorporation on some thermosensitive site. The possibility that these thermolabile sites are the mitochondria themselves is suggested by the demonstrated capacity of growth at elevated temperature or heat shock to induce the formation of respiratory-deficient (petite) mutants in yeast (Sherman, 1959). If this interpretation is correct, it would imply that growth in the presence of BrdU has an effect on the thermolability of mitochondria. A miscoding on the part of the halogenated percursor during the transcription of the messenger RNAs specifying the proteins of the inner mitochondrial membrane synthesized in the organelles (Ojala \& Attardi, 1974; Costantino \& Attardi, 1975) could account for this effect. Evidence of morphological changes induced in mitochondria by growth of $\mathrm{Cl}$ I D cells in the presence of BrdU has been previously presented (Clayton \& Teplitz, 1972).

\section{REFERENCES}

Attardi, B. \& Attardi, G. (1972). Persistence of thymidine kinase activity in mitochondria ot a thymidine-kinase-deficient derivative of mouse L cells. Proc. natn. Acad. Sci. U.S.A. 69, $2874-2878$.

Bogenhagen, D. \& Clayton, D. A. (I 974). The number of mitochondrial deoxyribonucleic acid genomes in mouse $\mathrm{L}$ and human HeLa cells. F. biol. Chem. 249, $799 \mathrm{I}-7995$.

Brown, S., TePlitz, M. \& Revel, J.-P. (I 974 ). Interaction of mycoplasmas with cell cultures, as visualized by electron microscopy. Proc. natn. Acad. Sci. U.S.A. 7r, 464-468.

Clayton, D. A. \& Teplitz, R. L. (1972). Intracellular mosaicism (nuclear $-/$ mitochondrial $^{+}$) for thymidine kinase in mouse L cells. F. Cell Sci. ro, 487-493.

Costantino, P. \& Attardi, G. (I975). Identification of discrete electrophoretic components among the products of mitochondrial protein synthesis in HeLa cells. 7. molec. Biol. (in Press). 
Croizat, B. \& AtTardi, G. (1975). Selective in vivo damage by 'visible' light of BrdU-containing mitochondrial DNA in a thymidine kinase-deficient mouse cell line with persistent mitochondrial enzyme activity. F. Cell Sci. 19, 69-84.

Djordjevic, B. \& SzYBalski, W. (1960). Genetics of human cell lines. III. Incorporation of 5-bromo- and 5-iododeoxyuridine into the deoxyribonucleic acid of human cells and its effect on radiation sensitivity. $\mathcal{F}$. exp. Med. 112, 509-531.

FLORY, P. J. \& VinOGRAD, J. (I 973). 5-Bromodeoxyuridine labeling of monomeric and catenated circular mitochondrial DNA in HeLa cells. F. molec. Biol. 74, 81-94.

Fox, E. \& Meselson, M. (1963). Unequal photosensitivity of the two strands of DNA in bacteriophage $\lambda$ (lambda). F. molec. Biol. 7, 583-589.

LeVintow, L. \& DARNELL, J. E. (I 960). A simplified procedure for purification of large amounts of poliovirus: characterization and amino acid analysis of type I poliovirus. $\mathcal{f}$. biol. Chem. 235, 70-73.

LitTLEFIELD, J. W. (1964). Three degrees of guanylic acid-inosinic acid pyrophosphorylase deficiency in mouse fibroblasts. Nature, Lond. 203, I I42-I I 44.

Marmur, J. (I96I). A procedure for the isolation of deoxyribonucleic acid from microorganisms. 7. molec. Biol. 3, 208-2 I 8.

Maroudas, N. G. \& Wilkie, D. (1968). Ultraviolet irradiation studies on the cytoplasmic determinant of the yeast mitochondrion. Biochim. biophys. Acta 166, 681-688.

Nagley, P. \& LinNane, A. W. (1972). Biogenesis of mitochondria. XXI. Studies on the nature of the molecular genome in yeast: the degenerative effects of ethidium bromide on mitochondrial genetic information in a respiratory competent strain. 7 . molec. Biol. 66, 181-193.

NASS, M. M. K. (I 969). Mitochondrial DNA. I. Intramitochondrial distribution and structural relations of single- and double-length circular DNA. F. molec. Biol. 42, $521-528$.

OJaLA, D. \& AtTARdi, G. (I974). Identification and partial characterization of multiple discrete polyadenylic acid-containing RNA components coded for by HeLa cell mitochondrial DNA. F. molec. Biol. 88, 205-219.

PuCK, T. T. \& KAO, F. T. (I967). Genetics of somatic mammalian cells. V. Treatment with 5 -bromodeoxyuridine and visible light for isolation of nutritionally deficient mutants. Proc. natn. Acad. Sci. U.S.A. 58, $1227-1234$.

SHERMAN, F. (I959). The effects of elevated temperatures on yeast. II. Induction of respiratorydeficient mutants. $\mathcal{F}$. cell. comp. Physiol. 54, 37-52.

Slonimski, P. P., Perrodin, G. \& Croft, J. H. (1968). Ethidium bromide induced mutation of yeast mitochondria: complete transformation of cells into respiratory deficient nonchromosomal 'petites'. Biochem. biophys. Res. Commun. 30, 232-239.

Sugimura, T., Okabe, K. \& Imamura, A. (I 966$)$. Number of cytoplasmic factors in yeast cells. Nature, Lond. 212, 304.

Szybalski, W. \& OpARA-Kubinska, Z. (1965). Radiobiological and physiochemical properties of 5 -bromodeoxyuridine-labeled transforming DNA as related to the nature of the critical radiosensitive structures. In Cellular Radiation Biology, 18th Symp. on Fundamental Cancer Research, pp. 223-240. Baltimore: Williams and Wilkins.

WILKIE, D. ( 1963 ). The induction by monochromatic UV light of respiratory-deficient mutants in aerobic and anaerobic cultures of yeast. $\mathcal{F}$. molec. Biol. 7, 527-533.

Williamson, D. H. (1970). The effect of environmental and genetic factors on the replication of mitochondrial DNA in yeast. In Control of Organelle Development (ed. P. L. Miller), pp. 247-276. Cambridge: Cambridge University Press.

(Received 24 March 1975) 